\title{
Personality and Social Relationships: As Thick as Thieves
}

\author{
Marcus Mund ${ }^{1}$, Bertus F. Jeronimus ${ }^{2,3}$, \& Franz J. Neyer ${ }^{1}$ \\ ${ }^{1}$ Friedrich-Schiller-Universität Jena, Germany
}

${ }^{2}$ University of Groningen, Department of Developmental Psychology, The Netherlands

${ }^{3}$ University of Groningen, University Medical Center Groningen, Department of Psychiatry,

Interdisciplinary Center Psychopathology and Emotion regulation (ICPE), The Netherlands

Chapter accepted for publication. Please cite this work as

Mund, M., Jeronimus, B. F., \& Neyer, F. J. (in press). Personality and social relationships: As thick as thieves. In C. Johansen (Ed.), Your personality makes you ill: Scientific proof or wishful thinking? San Diego: Elsevier.

This version might not exactly replicate the final version published in the book. It is not the copy of record. 


\section{Personality and Social Relationships: As Thick as Thieves}

Social relationships are part and parcel of an individual's life; in fact, because humans are social beings, a life without others would not be possible (Axelrod \& Hamilton, 1981; Baumeister \& Leary, 1995; Reis, Collins, \& Berscheid, 2000). Indeed, being socially included and surrounded by a network of others is crucial for health and longevity (Cohen, 2004; House, Landis, \& Umberson, 1988).

Social relationships are not assigned randomly to individuals. By contrast, the personality characteristics of individuals influence both the quantity and quality of their relationships and these aspects retroact on personality, as outlined throughout this chapter. Ultimately, this dynamic interaction between social relationships and personality affects an individual's health (see Figure 1). The model displayed in Figure 1 extends prior positions (e.g., Neyer \& Lehnart, 2006) in at least two major ways: First, we posit that neither personality traits nor social relationships affect health directly. ${ }^{1}$ Instead, we assume that most individual health outcomes emerge from the interplay between both domains. Second, we explicitly acknowledge that personality effects - effects of personality traits on the quantity and quality of social relationships - and relationship effects - effects of aspects of social relationships on personality_-vary in strength and nature as individuals proceed through time.

Throughout this chapter, we show that personality traits and social relationships interact over time. Specifically, we discuss (a) the role of personality traits in selecting and maintaining social relationships, (b) social relationship effects on personality development, and (c) specific life events from the perspective of personality-relationship transactions.

1 We acknowledge that personality traits may affect health outcomes above and beyond social relationships (for reviews, see Hampson \& Friedman, 2008; Roberts, Kuncel, Shiner, Caspi, \& Goldberg, 2007). However, even these apparently direct effects of personality are in fact indirect since they are transmitted through, for instance, health-related behaviors (for reviews, see Bogg \& Roberts, 2004; Hampson \& Friedman, 2008; Kern \& Friedman, 2011). 
Before we delve into these specific topics, we provide an overview of what kinds and aspects of social relationships and personality traits we focus on throughout the chapter.

\section{A Taxonomy of Social Relationships}

Individuals' social networks are highly differentiated and complex structures.

Research has distilled three core subnetworks based on the degree of emotional closeness and perceived reciprocity typically found in these relationships: (a) kin, (b) romantic partner, and (c) non-kin networks (Neyer, Wrzus, Wagner, \& Lang, 2011). Among the non-kin relationships, friendships stand out as particularly important, close, and stable across the lifespan (for reviews, see Hartup \& Stevens, 1997; Wrzus, Zimmermann, Mund, \& Neyer, 2016).

In the present chapter, we will focus on partner and friend relationships, since patterns of personality-relationship transactions and their effects on health outcomes are particularly well investigated in these relationships. The findings from these research strands thus serve as generic examples of the interplay between personality, relationships, and health and many of these findings presumably apply to other types of relationships as well.

Although the core networks of kin, partners, and non-kin—or variations thereofhave been considered in a large body of research (Asendorpf \& Wilpers, 1998; Mund \& Neyer, 2014; Neyer \& Asendorpf, 2001; Neyer \& Lehnart, 2007; Parker, Lüdtke, Trautwein, \& Roberts, 2012; Wrzus, Hänel, Wagner, \& Neyer, 2013), concrete relationships within each subnetwork can be further differentiated. Within the network of friends, for example, specific relationships might differ heavily with regard to aspects such as closeness or importance (e.g., pal vs. best friend). While research on partner relationships has a long tradition and has examined diverse aspects of this specific relationship, differences within the kin and non-kin networks have often been overlooked. Recently, however, an increasing number of studies 
has begun to also focus on the flux and flow of specific individual ties, thereby examining which ties come, go, and remain, and how aspects of specific relationships change over time (Branje, van Lieshout, \& van Aken, 2004; Greischel, Noack, \& Neyer, 2016; Sturaro, Denissen, van Aken, \& Asendorpf, 2008; Wagner, Lüdtke, Roberts, \& Trautwein, 2014; Zimmermann \& Neyer, 2013).

\section{Conceptions of Personality}

The study of stable inter-individual differences in the ways individuals think, feel, and behave - and hence, personality — has a long tradition. During this long history, research on personality sometimes went astray but became a serious scientific endeavor based on empirical findings in the 20th century (for in-depth reviews, see Barenbaum \& Winter, 2008; Dumont, 2010; Winter, John, Stewart, Klohnen, \& Duncan, 1998). In search of a parsimonious taxonomy of personality traits that would subsume the most basic betweenperson differences in thinking, feeling, and behaving, the Five-Factor-Model (FFM) emerged from psycholexical research (John, Naumann, \& Soto, 2008; McCrae \& Costa, 2008). As their basic traits, the FFM includes neuroticism, extraversion, openness, agreeableness, and conscientiousness.

Neuroticism refers to an individual's propensity to experience negative affect. More specifically, individuals scoring high on this trait are upset easily, irritable, impulsive, and more prone to negative feelings like anxiety and depression. Extraversion is characterized by the experience more frequent positive affective states, gregariousness, sociability, and assertiveness. Openness describes how inclined an individual typically is to seek for variety, novelty, and new experiences. Individuals high in agreeableness are characterized as being generally cooperative, altruistic, modest, and tender-minded. Finally, conscientiousness captures inter-individual differences in goal persistence, self-discipline and achievement 
striving (McCrae \& Costa, 2008). Each of these Big Five traits refers to a dimension on which everyone has a relative position, rather than describing a discrete type or class.

Although the FFM is currently the dominant model of individual differences in personality research, the concept of personality itself is much broader and more complex (McAdams, 1995; McAdams \& Pals, 2006; McCrae \& Costa, 2008). Furthermore, the FFM does not exhaustively cover the important aspects of personality, e.g., self-esteem or narratives (McAdams, 1995; McAdams \& Pals, 2006), among others. The Big Five are therefore not unopposed, and many critics argued that the FFM might help researchers to describe associations between personality and the outside world, but lack any explanatory power (Block, 1995; Cramer et al., 2012; Fleeson \& Jayawickreme, 2015; Wood, Gardner, \& Harms, 2015). Despite these criticisms, the FFM is still the most widely employed framework in research on the interplay between personality and social relationships, and therefore used to structure this chapter.

\section{Personality as a System Within Systems}

Although the research literature is not free of dispute on the optimal conceptualization of personality, it is widely acknowledged that personality, whether it is conceptualized in terms of the Big Five traits or otherwise, forms a complex dynamic system (Magnusson, 1990; Magnusson \& Törestad, 1993). The traits of the Big Five interact with each other and with other characteristics such as goals, values, and motives. As a consequence, the way from intra-individual behavioral dispositions to resulting overt behavior is a long and winding one. For instance, extraverted or conscientious behavior might be the result of the interplay between (a) underlying goals and (b) the degree to which an individual is able to enact these traits (Bleidorn, 2009; McCabe \& Fleeson, 2012, 2016), thus creating an intense intraindividual dynamic with different aspects of personality influencing each other (see also 
Fleeson \& Jayawickreme, 2015; Winter et al., 1998). However, life is not something that happens intra-individually. By contrast, an individual with its complex personality system is embedded in likewise complex systems surrounding it: the workplace, the society, the epoche, but most importantly: his or her system of social relationships. All these systems mutually interact and influence each other over time. This view, known as developmental systems approach (Lerner, 1996; Lerner \& Overton, 2008) or dynamic transactionism (Endler \& Magnusson, 1976; Magnusson, 1990; Magnusson \& Törestad, 1993) is key to understand how personality and social relationships influence each other to ultimately affect health (see Figure 1).

After having laid out the basics of social relationships, personality, and dynamic transactionism, we will now take a closer look at the research findings on the interplay between personality and both partner and friend relationships.

\section{My Partner and Me: Personality and Partner Relationships}

\section{Personality and Partner Selection}

Partnership selection is one of the most salient examples of environmental selection, and finding a suitable partner is certainly one of the most difficult interpersonal tasks individuals have to face in life, particularly during emerging and young adulthood (e.g., Hutteman, Hennecke, Orth, Reitz, \& Specht, 2014). If mastered successfully, however, satisfying partner relationships provide a multitude of benefits for one's health and wellbeing (for reviews, see Reis et al., 2000; Robles, Slatcher, Trombello, \& McGinn, 2014). With respect to personality traits, various studies have examined what "suitable" means in this regard. Generally, individuals seem to select partners that are similar to them with respect to personality. Concerning the Big Five traits, however, this similarity between partners is usually weak to moderate (Dyrenforth, Kashy, Donnellan, \& Lucas, 2010; Rammstedt \& 
Schupp, 2008; Watson et al., 2004) but considerably higher with regard to more specific areas of personality which are not covered by the Big Five traits such as values, attitudes, and political orientation (Watson et al., 2004).

As has been found in longitudinal studies with representative samples from Germany, $(\mathrm{N}=11,418)$, Australia $(\mathrm{N}=5,278)$, and the United Kingdom $(\mathrm{N}=6,554$; Dyrenforth et al., 2010) and in a cross-sectional study with a sample of 276 couples (Watson et al., 2004), similarity between partners in the Big Five does not seem to strongly influence the overall satisfaction with the relationship. Most studies on similarity have assumed linear effects, thereby neglecting the possibilities (a) that too much similarity might be as detrimental for relationship outcomes as too much dissimilarity and (b) that similarity on the low end of a trait dimension has different effects on the relationship as compared to similarity on the high end pole. Indeed, in two recent studies (Weidmann, Schönbrodt, Ledermann, \& Grob, 2017; Zhou, Wang, Chen, Zhang, \& Zhou, 2017) it was shown that the association between similarity and relationship satisfaction is more complex than previously thought. For instance, in a study with 237 couples, Weidmann et al. (2017) observed that couples in which both members had moderate levels of openness were more satisfied with their relationships two years later than couples whose members had similar high or low levels of openness or were dissimilar to each other.

Research on partner similarity requires relationships to be established. To examine what personality characteristics are valued most by potential partners, studies are required (a) to take place before partnerships have been established or even before potential partners have met for the first time, (b) assess personality traits of both potential partners, and (c) gather ratings of mutual interest. In fact, speed-dating combines all these advantages (Asendorpf, Penke, \& Back, 2011). In a pioneering study, Asendorpf et al. (2011) collected 
comprehensive data on the attractiveness of the voice, face, and physical appearance as well as various personality characteristics of 190 men and 192 women aged between 18 to 54 years. Participants were then given the opportunity to get to know each other in agehomogenous speed-dating sessions. In these sessions, each female participant interacted with each male participant for three minutes; this design led to a final sample of 2,160 dyads. Immediately after this brief contact, participants rated how they liked the interaction and whether they wanted to meet the interaction partner again privately outside the speed-dating context; contact information were only given away if the nomination for a private date was mutual. The study by Asendorpf et al. (2011) found a subordinate role for personality in this early stage of partner selection. Specifically, women were nominated for a subsequent date primarily for their attractiveness (i.e., if they had an attractive face and/or voice and a low body mass index), but not for their personality. By contrast, women with higher levels of shyness tended to nominate more men than less shy women. Men were also nominated for their appearance (i.e., attractive face and/or voice and low body mass index), sociodemographics (i.e., higher education and income), but also on base of their personality: men with higher levels of openness and lower levels of shyness were nominated more often.

On the other hand, personality of the male participants was not predictive of how many women they nominated for a subsequent date (Asendorpf et al., 2011). ${ }^{2}$

\section{Partner Relationships and Personality}

Socialization effects. Partner relationships can be strong forces when it comes to changing personality traits, as they organize our lives. Several studies have shown neuroticism to decrease as well as agreeableness, conscientiousness, and self-esteem to

2 Notably, in only $30 \%$ of the cases, men and women nominated mutually for a second date. Only six per cent of these matches have had sex with each other and only four per cent of the matches began a serious partner relationship (Asendorpf, Penke, \& Back, 2011). 
increase when individuals enter their first serious partner relationship (Lehnart, Neyer, \& Eccles, 2010; Neyer \& Asendorpf, 2001; Neyer \& Lehnart, 2007; Robins, Caspi, \& Moffitt, 2002; Wagner, Becker, Lüdtke, \& Trautwein, 2015; Wagner, Lüdtke, Jonkmann, \& Trautwein, 2013). Moreover, these effects do not vanish or reverse, even when the relationship has ended (Lehnart \& Neyer, 2006).

Socialization effects of the partnership might be consequences of intra-individual changes in both affective (e.g., Caughlin, Huston, \& Houts, 2000) and cognitive processes (e.g, Finn, Mitte, \& Neyer, 2015). For instance, in a prospective study with 245 couples that were repeatedly assessed over nine months, Finn et al. (2015) have found decreases in individuals' tendencies to interpret ambiguous situations that might arise in a relationship (e.g., "Your partner has not told you that s/he loves you for a longer time.") in a negative way (e.g., "S/He does not love me anymore"). However, these positive effects are bound to two conditions: First, relationships need time to exert their influence on personality traits, which is why socialization effects can only be observed in longer-term relationships (Lehnart \& Neyer, 2006; Mund, Finn, Hagemeyer, \& Neyer, 2016), while personality effects prevail in shorter-term relationships (Lehnart \& Neyer, 2006; Robins et al., 2002). Second, longer-term relationships need to be positive to influence personality in a likewise positive way; longerterm relationships with many conflicts or even abuse appear to have detrimental effects on personality development (Robins et al., 2002).

Personality effects. Although relationships affect personality traits in the long run, their influence is typically not so large that individuals would come out twisted. Instead, individuals contribute their personality characteristics and have to negotiate with their partners how these can be enacted properly within the relationship.

A multitude of studies has investigated how an individual's personality affects his or 
her partner relationship, mostly in terms of one or more aspects of relationship quality. One of the most consistent findings of this individual-level research is that neuroticism and associated traits are detrimental for an individual's perception of the relationship. That is, neuroticism has been consistently found to be associated with lower relationship quality and a higher risk of separation (Heller, Watson, \& Ilies, 2004; Karney \& Bradbury, 1995). High conscientiousness and agreeableness, in contrast, are both predictive of more secure attachment, better relationship quality, and lower divorce rates (Noftle \& Shaver, 2006; Roberts, Kuncel, Shiner, Caspi, \& Goldberg, 2007). Conscientiousness is further associated with sexual fidelity (Schmitt, 2004), while agreeableness predicts lower levels of conflict (Asendorpf \& Wilpers, 1998), among others.

However, it is trivial to state that couples necessarily consist of two partners; but only during the last decade, an increasing number of studies have taken this triviality into account by adopting dyadic designs (Kenny, Kashy, \& Cook, 2006). In such designs, the interdependence between members of a couple can be disentangled and hence allow to more closely investigate intrapersonal effects and interpersonal effects. Even after controlling for the interdependence among couple members, studies employing a dyadic design have still found a major role for neuroticism in predicting lower relationship quality and an increased risk for separation, but also documented effects for other Big Five traits (for a review, see Mund et al., 2016). Shifting the attention away from intrapersonal effects, studies with dyadic designs have also found interpersonal effects, which indicate to what extent an individual's personality influences the relationship quality of his or her partner. Again, neuroticism turned out to be the most influential trait in this regard (for reviews, see Malouff, Thorsteinsson, Schutte, Bhullar, \& Rooke, 2010; Mund et al., 2016). In most cases, however, interpersonal effects can be assumed to be weaker than intrapersonal effects, because the interpersonal 
transmission of one partner's personality to the other partner is even more complex than within-person transmissions (for a review, see Mund et al., 2016).

Interpersonal transmission may be stronger in specific subgroups of the population, however, which may be disguised by weak overall effects. Taking neuroticism as an example, previous reviews outlined that individuals high (versus low) on neuroticism tend to select themselves into rather unstable and unsatisfying relationships that are full of conflict and even abuse (Buss, 2003; Jeronimus, 2015; Karney \& Bradbury, 1997). Neuroticism also predicts the annual prevalence of infidelity after controlling for sex, age, education, and race, and even after controlling for marital dissatisfaction. Consequently, neuroticism is more predictive of relationship dissolution than socioeconomic status or intelligence (Buss, 2003; Roberts et al., 2007). Neuroticism thus captures individual differences in how individuals perceive, construe, and feel about social reality, which influence how they respond to it, and in dynamic interaction with conscientiousness and other personality phenomena, can have a substantial role in mental and somatic health (Amato, 2000; Cuijpers et al., 2010; Jeronimus, Kotov, Riese, \& Ormel, 2016; Sbarra, 2015).

Relationship effects. In addition to the effects that partners directly have on each other via the interplay between intrapersonal processes and overt behavior (Mund et al., 2016), specific aspects of the relationship might also influence personality development. For instance, Mund and Neyer (2014) found aspects such as emotional closeness, insecurity, and conflict frequency to affect long-term changes in neuroticism, extraversion, agreeableness, and conscientiousness in a longitudinal study with 654 individuals that were assessed three times across 15 years. Moreover, changes in relationship aspects were likewise predictive of subsequent changes in these personality traits, which corroborates the notion of the interplay between personality and the partner relationship being highly dynamic (Mund \& Neyer, 
2014). While neuroticism has been found to increase almost linearly when individuals experiences increases in conflict, negativity, dissatisfaction, insecurity, and abuse in their

relationship, it has been found to decrease over time in happy relationships (Jeronimus, 2015; Robins et al., 2002).

Taken together, the findings reviewed above indicate a minor role for personality in selecting or being selected as a partner in the first place. However, similarity, particularly in specific personality characteristics, seems to be important to establish a longstanding partner relationship. Succeeding in establishing a partner relationship has been found to positively affect personality development, for instance by influencing affective and cognitive process. As the relationship lasts, partners begin to influence each other via behavioral interactions, that are themselves results of dynamic intrapersonal processes. Notably, this process of mutual influence does not stop but continues across the lifespan (at least the lifespan of the relationship).

\section{My Friends and Me: Personality and Friendships}

\section{Personality and Friend Selection}

As soon as children get into contact with each other, they will select friends (Hartup \& Stevens, 1997). Across the lifespan, the meaning of friendship changes from playfellow to confidant (Hartup \& Stevens, 1997; Wrzus \& Neyer, 2016). In general, the sheer number of friendships decreases across the adult lifespan (Wrzus et al., 2013); in contrast, emotional closeness towards the friends that remain in one's network can be expected to increase with age (Carstensen, 1992, 1995; Wrzus \& Neyer, 2016; for a detaile review, see Wrzus et al., 2016). Since friendships are self-selected relationships, numerous studies have addressed the question of who selects whom to be his or her friend.

While extraversion and agreeableness have been found to be related to the number of 
self-reported friendships (Anderson, John, Keltner, \& Kring, 2001; Asendorpf \& Wilpers, 1998), the question which personality characteristics are liked in a potential future friend is more difficult to answer. With respect to the research design, addressing this question requires zero acquaintances — individuals who do not know each other- to be followed over time to examine who befriends whom. This has been done in two pertinent studies with samples of 73 (Back, Schmukle, \& Egloff, 2011) and 205 (Selfhout et al., 2010) psychology freshmen. Back et al. (2011) used a round-robin design in which each individual rated all other individuals and was rated him or herself by all others on a variety of characteristics (for an introduction, see Nestler, Grimm, \& Schönbrodt, 2015), leading to an effective sample of 2,628 dyads. In a different approach, after assessing their personality traits at zero acquaintance, Selfhout et al. (2010), investigated which individuals of their sample became friends during their first year at university. Findings of these studies indicate that extraverted and agreeable individuals are more popular at first sight, that is, they are more often nominated as potential friends (Back et al., 2011; Selfhout et al., 2010). This might be due to particularly individuals high in extraversion signaling their sociability to others, for instance, by smiling and appearing more approachable (Back et al., 2011). By contrast, highly extraverted individuals do not select their friends haphazardly: there is no association between extraversion and the number of friends selected by individuals. However, somewhat paradoxical associations have been found between being a liker (i.e., nominating many others as potential friends), popularity (being selected as a potential friend), and self-centered values, a personality characteristic that is related to narcissism. Specifically, individuals with more pronounced self-centered values tend to dislike other individuals but are more often nominated as potential friends than individuals with less self-centered values (Back et al., 2011; for a detailed review, see Wrzus et al., 2016). 
As with partner relationships, similarity also plays a role in establishing friendships. Specifically, while the studies by both Back et al. (2011) and Selfhout et al. (2010) have found evidence for the interplay between personality and friend selection, the most powerful condition for friendships to emerge in these two studies was the similarity between individuals in both superficial aspects such as clothing (Back et al., 2011) ${ }^{3}$ and Big Five personality traits, particularly extraversion and agreeableness (Selfhout et al., 2010). Furthermore, while personality characteristics and their behavioral expressions seem important for the first impression, similarity_again particularly concerning more specific personality characteristics such as political orientation—seems to play a major role when it comes to establishing an enduring friendship (Bahns, Crandall, Gillath, \& Preacher, 2017; Selfhout et al., 2010).

\section{Friendships and Personality}

Personality effects. Personality traits contribute to the quality of a friendship. For instance, prior longitudinal studies have found that (a) neuroticism is related to increased insecurity towards friends, (b) extraversion is related to higher contact frequency, greater importance of as well as higher emotional closeness towards friends, and (c) conscientiousness is related to less insecurity towards friends (Asendorpf \& Wilpers, 1998; Mund \& Neyer, 2014; Neyer \& Asendorpf, 2001; Parker et al., 2012). Personality effects on friendships are particularly strong in phases of transition. For instance, both Asendorpf and Wilpers $(1998, \mathrm{~N}=132)$ and Parker et al. $(2012, \mathrm{~N}=2,173)$ examined individuals in the transition from high school to university, and exclusively found personality effects on several aspects of friendship quality, but not vice versa.

Relationship effects. Friends provide important contexts for personality development 
throughout the lifespan. For instance, friendships in childhood are centered around playing, while in adolescence, friends successively replace parents as confidants and serve as an experimental field for later partner relationships (for detailed reviews, see Hartup \& Stevens, 1997; Wrzus et al., 2016). According to these functional changes, the effects of friendships on personality traits differ across the lifespan (Wrzus \& Neyer, 2016). For instance, in young and middle adulthood, higher levels of conflicts with friends and insecurity towards friends increases neuroticism over time (Mund \& Neyer, 2014). ${ }^{4}$ However, conflicts in close relationships may be a double-edged sword, as individuals learn that relationships persist even if they disagree with important others (Laursen \& Hafen, 2010), but frequent conflicts might lead individuals to question not only the relationship but also themselves. Also friendships need time and stability to exert influences on personality traits, which is corroborated by the notion that in time of transitions, no relationship effects can be found (Asendorpf \& Wilpers, 1998; Parker et al., 2012).

To summarize, personality traits and their behavioral manifestations (e.g., clothing style, frequent smiling) play an important role for liking at zero acquaintance. To further develop this initial liking into a friendship, individuals need to have something in common, and as with partner relationships, this "something" is apparently more specific than the Big Five personality traits (e.g., political orientation, attitudes, preferences). If a relationship is formed, both friends' personality traits shape the relationship; if the friendships persists over a longer time period, the relationship will begin to retroact on the friends' personality traits. While research on partner relationships has evinced an increasing number of dyadic longitudinal studies, similar designs are lacking in the realm of friendships. Although it might always). 
be difficult and of uncertain value to track the interplay between the personality characteristics of two friends and their perceived relationship quality over time, future research might certainly benefit from paying attention to the development of multiple specific friend relationships in favor of examining the development of aggregated friend networks. Furthermore, future research might also implement designs more frequently in which friends provide information about one another (round-robin designs; see Nestler et al., 2015). In this way, it might also be possible to elucidate personality-related factors that lead to the end of friendships or to a high fluctuation within individuals' friend networks.

\section{Interim Conclusion: What Does All This Mean and How Does it Relate to Health?}

In the previous sections, we have reviewed evidence for the notion that partner and friend relationships dynamically interact with personality traits. This interplay is itself subject to time-specific variations: at some times, personality effects on a partner relationship may be stronger than the respective reciprocal effects, while later in time, the relationship might have stronger effects on an individual's personality than he or she has on the relationship (see Figure 1). To disentangle these double dynamics between personality and social relationships, clearly, more longitudinal studies are needed, ideally complemented with intermediate diary studies to also capture shorter-term dynamics (for a similar argument, see Mund et al., 2016). But how is this double dynamic related to health outcomes?

On the most general level, relationships can act either as stress buffers or as sources of stress (Cohen, 2004) — or both in a dynamic fashion. For instance, in two studies with 314 and 150 individuals, respectively, Wrzus et al. (2012) have found tpoor kin relationships to have detrimental effects on well-being. These negative effects, however, can be buffered and even compensated by particularly close friendships. Recall that whether individuals can select and maintain close friendships is, at least partly, affected by their personality traits. With 
respect to partner relationships, relationship satisfaction has been found to positively affect health outcomes (Bos, Snippe, De Jonge, \& Jeronimus, 2016; Robles et al., 2014).

Whether a relationship is perceived as satisfying might be the result of another transaction cycle between partners. For instance, if conflict frequency increases and emotional closeness between partner decreases, both partners might begin to experience declines in their relationship quality. One of the partners - presumably the one with higher neuroticism - might begin to increasingly interpret several actions by the other partner as indicators of rejection or criticism (Finn et al., 2015) and become more sensitive for the slightest signs of threats to the relationship. As a consequence, he or she might feel insecure and possibly even begins to ruminate about both the relationship and him- or herself as a person. These ruminations might foreshadow depressive symptoms (Nolen-Hoeksema, 2000; Nolen-Hoeksema, Wisco, \& Lyubomirsky, 2008) but also lead him or her to more readily start arguments due to his or her hurt feelings; and these arguments might end in bitter fights (Karney \& Bradbury, 1997; McNulty, 2008). After some time, however, the stressor that set this vicious circle in motion, might have disappeared. Both couple members might sit together and calmly discuss this passed terrible episode of their relationship and continue their relationship. In a less positive scenario, they might divorce, which has well-known detrimental consequences for health and well-being (Amato, 2000; Luhmann \& Eid, 2009). This admittedly extreme example shows how features of the relationship (increasing conflicts) and personality characteristics (neuroticism, cognitive styles) interact over time to exert both shorter-term (rumination) and longer-term (depression) influences on health. In support of this line of reasoning, several studies have shown how personality-relationship transactions influence the transition to parenthood (Marshall, Simpson, \& Rholes, 2015, N = 192 couples), and recovery after a bypass surgery (Ruiz, Matthews, Scheier, \& Schulz, 2006, 
$\mathrm{N}=111$ patients and their caregivers) as well as following brain injury (Haller, 2017, $\mathrm{N}=$ 376 patients and their relatives).

Personality-relationship transaction do not only vary with time. Life events might additionally affect how individuals interact with their social environment, as outlined in the following section.

\section{Adding Another Level of Complexity: The Role of Life Transitions}

Individuals do not progress linearly through their lives. Instead, individuals undergo transitions (e.g., from college to work) and adopt new social roles (e.g., the role as an employee or the role as a parent; Hutteman et al., 2014; Rindfuss, 1991). These transitions can roughly be differentiated based on their normativeness, that is, by whether they (a) occur frequently or rarely and (b) come with or without behavioral scripts (Caspi \& Moffitt, 1993; Neyer, Mund, Zimmerman, \& Wrzus, 2014). Frequent life transitions such as entering the labor force do hardly allow for selection effects, since most individuals undergo this transition. Rare life transitions, in contrast, might be selected by individuals based on their personality traits. Life transitions entailing strong behavioral scripts have been shown to foster differential personality development (for a discussion on different aspects of personality development, see Mund, Zimmermann, \& Neyer, in press). This means that individuals experiencing a strongly scripted transition differ in terms of pace or direction of personality development from individuals who have not (yet) experienced this transition. As a consequence, inter-individual differences in personality are de-stabilized (Caspi \& Moffitt, 1993; Neyer et al., 2014). By contrast, between-person differences in personality are strengthened when individuals have more opportunity to act out their existing personality traits - that is, when selecting into life transitions that do not provide information on how to behave. The repeated occurrence of such less normative life events leads to a stabilization of 
inter-individual differences in the long run (Caspi \& Moffitt, 1993; Neyer et al., 2014).

It is well established that life transitions can be accompanied by small but meaningful changes in personality (Jeronimus, Riese, Sanderman, \& Ormel, 2014; Specht, Egloff, \& Schmukle, 2011; Sutin, Costa, Wethington, \& Eaton, 2010) and most of the major transitions in life directly or indirectly affect the social domain (Lang, Reschke, \& Neyer, 2006) and thus affect, among other things, the size, composition, and patterns of interactions with individual's social networks (Lang et al., 2006; Wrzus et al., 2013). In fact, the life transitions that have been found to most strongly affect personality development have also been found to strongly affect the development of social networks (see Figure 2). Thus, while patterns of personality-relationship transactions fluctuate naturally over time, life transitions might further amplify or reverse these patterns, as displayed in Figure 3. Notably, we assume that most life transitions, whether normative or not, affect personality-relationship transactions even before the event of interest has even occurred (Luhmann, Orth, Specht, Kandler, \& Lucas, 2014; Wood \& Roberts, 2006a, 2006b). Parenthood, for instance, potentially affects personality traits and interpersonal contacts before the actual birth of the child since both parents-to-be have to prepare for their new role. This is one example in which preconceptions of a future identity — an intrapersonal influence — can change personality in anticipation of a future social role.

\section{Personality Effects}

Personality characteristics have been found to affect the circumstances and environments and hence the life transitions individuals select into (Jeronimus et al., 2014; Magnus, Diener, Fujita, \& Pavot, 1993; Specht et al., 2011). Such personality effects describe how individuals create their niches by (a) situation selection (specific situations are selected or avoided), (b) evocation (personality traits and their behavioral manifestations evoke 
specific responses from the environment), and (c) manipulation (individuals change the specifics of their environment; Buss, 1987; Laceulle, Jeronimus, van Aken, \& Ormel, 2015). It should be noted, though, that these mechanisms are not mutually exclusive and that the passage between them can be fluent. As a consequence, research on personality effects is most often concerned with selection effects. In such studies, it has been found that personality traits are predictive of going abroad for an academic year (Greischel et al., 2016, $\mathrm{N}=741$; Zimmermann \& Neyer, 2013, $\mathrm{N}=1,134$ ), living arrangements (Jonkmann, Thoemmes, Lüdtke, \& Trautwein, 2014, N = 8,052; Specht et al., 2011, $N=14,718$ ), entering a romantic relationship (Lüdtke, Roberts, Trautwein, \& Nagy, 2011, N = 4,544; Neyer \& Lehnart, 2007, $\mathrm{N}=225$ ), and relationship breakup (Lehnart \& Neyer, 2006; Lüdtke et al., 2011; Specht et al., 2011), among many other things.

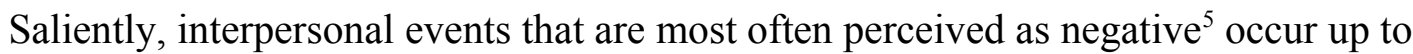
three times more frequent among individuals from the highest quartile of neuroticism compared to the lowest quartile (Fergusson \& Horwood, 1987; Magnus et al., 1993; Poulton \& Andrews, 1992; Specht et al., 2011; van Os, Park, \& Jones, 2001). Conscientiousness predicts the occurrence of fewer negative events (Lüdtke et al., 2011). Positive experiences, in contrast, are predicted by extraversion (Lüdtke et al., 2011; Magnus et al., 1993; Vaidya, Gray, Haig, \& Watson, 2002), but not by neuroticism (Jeronimus, Ormel, Aleman, Penninx, \& Riese, 2013; Jeronimus et al., 2014; Magnus et al., 1993). Openness appears to be a double-edged sword in this regard since it has been found to predict the occurrence of both more positive and negative events (Lüdtke et al., 2011). Although the effect sizes are typically small, such selection effects might accumulate over time since individuals select

5Although distinguishing life transitions in terms of their valence (positive vs. negative) is not ideal since one and the same event can be perceived as positive by one individual but negative by another individual or both positive and negative at the same time (Lüdtke, Roberts, Trautwein, \& Nagy, 2011), we keep this distinction here since it is widely used in the literature. 
into positive and negative events over and over again (Caspi et al., 2016; Jeronimus et al., 2014).

\section{Socialization Effects}

Socialization effects - the effects that life transitions exert on personality traits and their development — are most likely to occur during normative life transitions, that is, during transitions that result in new social roles and provide relatively strong behavioral scripts (Bleidorn, Hopwood, \& Lucas, 2016; Neyer et al., 2014; Roberts \& Nickel, 2017). Such normative transitions may have a lasting effect on personality because they modify, interrupt, or redirect life trajectories (Bleidorn et al., 2016; Lodi-Smith \& Roberts, 2007). However, not all data is consistent with this notion. Studies, for instance, on parenthood—a rather normative life transition-yielded contradictory results. In some studies, parenthood did not influence personality development, while in others, it predicted development in a direction that is typically considered socially less desirable (e.g., increases in neuroticism or decreases in conscientiousness; Jokela, Alvergne, Pollet, \& Lummaa, 2011; Jokela, Kivimäki, Elovainio, \& Keltikangas-Järvinen, 2009; Specht et al., 2011; van Scheppingen et al., 2016).

Despite these empirical inconsistencies with regard to the effects of some specific life events (for an overview, see Specht, 2017), it has now been documented in a large body of research that life transitions that are experienced as positive by most individuals (e.g., entering a romantic relationship, finding a job) are followed by small but persistent decreases in neuroticism as well as small increases in extraversion, openness, agreeableness, and conscientiousness (Jeronimus et al., 2013, 2014; Lüdtke et al., 2011; Specht et al., 2011; Vaidya et al., 2002). Life transitions that are perceived as negative by most individuals (e.g., unemployment, divorce), in contrast, have been found to be followed by increases in neuroticism as well as decreases in openness, agreeableness, and conscientiousness 
(Jeronimus et al., 2014; Löckenhoff, Terracciano, Patriciu, Eaton, \& Costa, 2009; Lüdtke et al., 2011; Riese et al., 2014; Specht et al., 2011; Vaidya et al., 2002).

Socialization effects of most life transitions are particularly strong during the first three months after the occurrence of the transition. However, these state effects have often been found to recede within six months after the transition (Jeronimus et al., 2013, $\mathrm{N}=2,356$; Riese et al., 2014, $\mathrm{N}=21,085$; for a review, see Ormel, VonKorff, Jeronimus, \& Riese, 2017). Changes in personality traits that persist longer than six months are therefore thought to reflect "true" personality change, which can then persist for years to decades (Jeronimus et al., 2014; Mund \& Neyer, 2014). Differences in such personality dynamics have not been fleshed out completely, as this requires the repeated assessment of large samples, ideally at least every three months over several decades. Nonetheless, adaptations after retirement or marriage appear to take one to two years, for example, whereas adaptation to disability or the death of a spouse or child may take more than a decade (see Figure 4), if ever.

Events that are perceived as positive by most individuals typically have stronger short-term effects on personality traits and occur more frequently in general. The effects of negative life events, in contrast, have been found to persist much longer (Jeronimus et al., 2014). Positive and negative experiences can also have concurrent and complementary sequential relationships, such as in cycles of marriage and divorce. Positive events can even buffer the impact of negative events (Dohrenwend, 2006; Longua, Dehart, Tennen, \& Armeli, 2009) and thus increase resiliency (Garland et al., 2010).

To summarize, individuals select into particular environments and head to specific life transitions partly based on their personality characteristics. The most influential of these life transition are social in nature and retroact on core aspects of personality through the shifts in the social environment and patterns in personality-relationship transactions. Whether life 
events contribute to the stabilization of inter-individual differences in personality or to differential development depends on their normativeness - the degree to which life transitions are predictable and equipped with behavioral scripts. Generally speaking, life transitions that are undesirable in the view of most individuals are associated with increases in neuroticism and therewith most risk factors for health problems. Rather positive life transitions, in contrast, appear to foster personality development in a socially more desirable direction.

\section{Future Directions and Open Questions}

Although the last two decades have witnessed an increasing number of studies focusing on the interplay between various personality traits and different aspects of social relationships, future research still has to meet several challenges in order to advance the understanding of this interplay and its consequences for health. Broadly, these challenges are clustered around (a) conceptual issues and (b) methodological issues.

With regard to conceptual issues, future research might further unravel how interindividual differences in personality are connected to inter-individual differences in the composition of social networks, thereby also taking into account the interplay between different interaction partners or subnetworks (e.g., spill-over or compensatory effects). To understand such cross-network interactions, it will be necessary to investigate personalityrelationship dynamics in contexts beyond partner and friend relationships. For instance, not much is known about dynamic transactions among colleagues - relationship partners that individuals spend a large amount of time with and that certainly have an influence on physical and mental health (e.g., mobbing, workplace conflicts, but also buffering stress through a good working climate; Fang et al., 2015; Landis, 2016; Reitz, Zimmermann, Hutteman, Specht, \& Neyer, 2014). Furthermore, future research might more strongly focus on assessing specific ties instead of broader person-centered networks. Above and beyond the 
benefits of tracking specific ties mentioned earlier in this chapter, it would also become possible to track the development of specific ties (e.g., from colleague to friend, from friend to partner, from partner to ex-partner). This would enable future research to shed light on the causes and consequences of changes in patterns of personality-relationship transactions. These conceptual issues are closely linked with issues of measurement and research design. Current research on personality-relationship transactions has a toolbox fully packed with innovative and informative measurement and analysis tools (Nestler et al., 2015; Wrzus \& Mehl, 2015). Future research will benefit from employing these tools more frequently and advance them according to specific research questions. For instance, although longitudinal studies have been and will continue to be of utmost importance to investigate personalityrelationship transactions and their consequences on health, future research might benefit from a finer-grained resolution of dynamics within networks and over shorter time periods. This could be done, for instance, by enriching longitudinal studies with interspersed diary or experience-sampling phases (Mund et al., 2016), all the more since programming of such studies is much easier nowadays than it was several years before (Thai \& Page-Gould, in press). As an additional surplus, such designs would also allow researchers to examine the long-term consequences of short-term variation in personality traits, aspects of social relationships, and the interplay between personality and social relationships. To circumvent the pitfalls of the exclusive reliance on self-reports, future research might also more routinely utilize social media messages (e.g., Facebook, Twitter, Instagram; de Choudhury, Gamon, Counts, \& Horvitz, 2013; Kosinski, Stillwell, \& Graepel, 2013), or behavioral residuals (Gosling, 2008) to uncover how personality processes affect various aspects of health. In addition to the typical longitudinal study, in which a sample is drawn at a given point in time and maintained as good as possible, alternative sampling strategies such as 
crowdfunding studies might become increasingly attractive (for an example, see van der Krieke et al., 2015). In such designs, a large pool of potential participants is offered to participate in a variety of studies. The advantage of this sampling strategy is that participants can join the pool whenever they want and select the studies that they are most interested in. Researchers, on the other hand, are not bound to a pre-specified set of questions or studies but instead can design new questionnaires or diary studies anytime (for an application with a sample of 629 individuals participating in a 30-day diary study, see van der Krieke et al., 2016).

Finally, particularly with respect to understanding how life transitions may alter patterns of personality-relationship transactions, it will be important for future research to treat time more carefully (Luhmann et al., 2014; Mund et al., in press). Specifically, most current research treats time in terms of measurement occasions, which in most cases are chosen arbitrarily. By centering analyses around the occurrence of an event, it will be possible for future research to gain a deeper understanding of how changes in the patterns of personality-relationship transactions around a given life transition affect health outcomes and to more closely investigate the processes underlying these effects.

\section{Conclusion}

In this chapter, we have shown that personality traits and social relationships are deeply entwined in a bidirectional way: Individuals select relationships partly based on their personality traits but at the same time develop across the lifespan partly in response to changes in their social environment. Furthermore, life transitions are an important catalyst of changes in personality-relationship transactions, although their effects on the concrete interplay between both domains requires further research. In fact, we argue that personality traits and social relationships are so closely tied that, in our view, the link between 
personality and health can only be understood against the backdrop of individuals' relationships. 


\section{References}

Amato, P. R. (2000). The consequences of divorce for adults and children. Journal of Marriage and Family, 62, 1269-1287. https://doi.org/10.1111/j.17413737.2000.01269.x

Anderson, C., John, O. P., Keltner, D., \& Kring, A. M. (2001). Who attains social status? Effects of personality and physical attractiveness in social groups. Journal of Personality and Social Psychology, 81, 116-132. https://doi.org/10.1037/00223514.81 .1 .116

Asendorpf, J. B., Penke, L., \& Back, M. D. (2011). From dating to mating and relating: Predictors of initial and long-term outcomes of speed-dating in a community sample. European Journal of Personality, 25, 16-30. https://doi.org/10.1002/per.768

Asendorpf, J. B., \& Wilpers, S. (1998). Personality effects on social relationships. Journal of Personality and Social Psychology, 74, 1531-1544. https://doi.org/10.1037/00223514.74.6.1531

Axelrod, R. M., \& Hamilton, W. D. (1981). The evolution of cooperation. Science, 211, $1390-1396$.

Back, M. D., Schmukle, S. C., \& Egloff, B. (2011). A closer look at first sight: Social relations lens model analysis of personality and interpersonal attraction at zero acquaintance. European Journal of Personality, 25, 225-238. https://doi.org/10.1002/per.790

Bahns, A. J., Crandall, C. S., Gillath, O., \& Preacher, K. J. (2017). Similarity in relationships as niche construction: Choice, stability, and influence within dyads in a free choice environment. Journal of Personality and Social Psychology, 112, 329-355. https://doi.org/10.1037/pspp0000088

Barenbaum, N. B., \& Winter, D. G. (2008). History of modern personality theory and research. In O. P. John, R. W. Robins, \& L. A. Pervin (Eds.), Handbook of personality: Theory and research (3rd ed.). (pp. 3-26). New York, NY, US: Guilford 
Press.

Baumeister, R. F., \& Leary, M. R. (1995). The need to belong: Desire for interpersonal attachments as a fundamental human motivation. Psychological Bulletin, 117, 497529. https://doi.org/10.1037/0033-2909.117.3.497

Bleidorn, W. (2009). Linking personality states, current social roles and major life goals. European Journal of Personality, 23, 509-530. https://doi.org/10.1002/per.731

Bleidorn, W., Hopwood, C. J., \& Lucas, R. E. (2016). Life events and personality trait change. Journal of Personality, early view. https://doi.org/10.1111/jopy.12286

Block, J. (1995). A contrarian view of the five-factor approach to personality description. Psychological Bulletin, 117, 187-215. https://doi.org/10.1037/0033-2909.117.2.187

Bogg, T., \& Roberts, B. W. (2004). Conscientiousness and health-related behaviors: A metaanalysis of the leading behavioral contributors to mortality. Psychological Bulletin, 130, 887-919. https://doi.org/10.1037/0033-2909.130.6.887

Bos, E. H., Snippe, E., De Jonge, P., \& Jeronimus, B. F. (2016). Preserving subjective wellbeing in the face of psychopathology: Buffering effects of personal strengths and resources. PLoS ONE, 11, e0150867. https://doi.org/10.1371/journal.pone.0150867

Branje, S. J. T., van Lieshout, C. F. M., \& van Aken, M. A. G. (2004). Relations between Big Five personality characteristics and perceived support in adolescents' families. Journal of Personality and Social Psychology, 86, 615-628. https://doi.org/10.1037/0022-3514.86.4.615

Buss, D. M. (1987). Selection, evocation, and manipulation. Journal of Personality and Social Psychology, 53, 1214-1221. https://doi.org/10.1037/0022-3514.53.6.1214

Buss, D. M. (2003). The evolution of desire: Strategies of human mating. New York: Basic Books.

Carstensen, L. L. (1992). Social and emotional patterns in adulthood: Support for socioemotional selectivity theory. Psychology and Aging, 7, 331-338. https://doi.org/10.1037/0882-7974.7.3.331 
Carstensen, L. L. (1995). Evidence for a life-span theory of socioemotional selectivity. Current Directions in Psychological Science, 4, 151-156. https://doi.org/10.1111/1467-8721.ep11512261

Caspi, A., Houts, R. M., Belsky, D. W., Harrington, H., Hogan, S., Ramrakha, S., \& Moffitt, T. E. (2016). Childhood forecasting of a small segment of the population with large economic burden. Nature Human Behaviour, 1. https://doi.org/10.1038/s41562-0160005

Caspi, A., \& Moffitt, T. E. (1993). When do individual differences matter? A paradoxical theory of personality coherence. Psychological Inquiry, 247-271. https://doi.org/10.1207/s15327965pli0404_1

Caughlin, J. P., Huston, T. L., \& Houts, R. M. (2000). How does personality matter in marriage? An examination of trait anxiety, interpersonal negativity, and marital satisfaction. Journal of Personality and Social Psychology, 78, 326-336. https://doi.org/10.1037//0022-3514.78.2.326

Cohen, S. (2004). Social relationships and health. American Psychologist, 59, 676-684. https://doi.org/10.1037/0003-066X.59.8.676

Cramer, A. O. J., van der Sluis, S., Noordhof, A., Wichers, M., Geschwind, N., Aggen, S. H., ... Borsboom, D. (2012). Dimensions of normal personality as networks in search of equilibrium: You can't like parties if you don't like people. European Journal of Personality, 26, 414-431. https://doi.org/10.1002/per.1866

Cuijpers, P., Smit, F., Penninx, B. W., de Graaf, R., ten Have, M., \& Beekman, A. T. (2010). Economic costs of neuroticism: A population-based study. Archives of General Psychiatry, 67, 1086-1093. https://doi.org/10.1001/archgenpsychiatry.2010.130 de Choudhury, M., Gamon, M., Counts, S., \& Horvitz, E. (2013). Predicting Depression via Social Media. Presented at the Association for the Advancement of Artificial Intelligence (AAAI).

Dohrenwend, B. P. (2006). Inventorying stressful life events as risk factors for 
psychopathology: Toward resolution of the problem of intracategory variability. Psychological Bulletin, 132(3), 477-495. https://doi.org/10.1037/00332909.132.3.477

Dumont, F. (2010). A history of personality psychology: Theory, science, and research from Hellenism to the twenty-first century. New York: Cambridge University Press.

Dyrenforth, P. S., Kashy, D. A., Donnellan, M. B., \& Lucas, R. E. (2010). Predicting relationship and life satisfaction from personality in nationally representative samples from three countries: The relative importance of actor, partner, and similarity effects. Journal of Personality and Social Psychology, 99, 690-702. https://doi.org/10.1037/a0020385

Endler, N. S., \& Magnusson, D. (1976). Toward an interactional psychology of personality. Psychological Bulletin, 83, 956-974. https://doi.org/10.1037/0033-2909.83.5.956

Fang, R., Landis, B., Zhang, Z., Anderson, M. H., Shaw, J. D., \& Kilduff, M. (2015). Integrating personality and social networks: A meta-analysis of personality, network position, and work outcomes in organizations. Organization Science, 26, 1243-1260. https://doi.org/10.1287/orsc.2015.0972

Fergusson, D. M., \& Horwood, L. J. (1987). Vulnerability to life event exposure. Psychological Medicine, 17(3), 739-749. https://doi.org/10.1017/S0033291700025976

Finn, C., Mitte, K., \& Neyer, F. J. (2015). Recent decreases in specific interpretation biases predict decreases in neuroticism: Evidence from a longitudinal study with young adult couples. Journal of Personality, 83, 274-286. https://doi.org/10.1111/jopy.12102

Fleeson, W., \& Jayawickreme, E. (2015). Whole Trait Theory. Journal of Research in Personality, 56, 82-92. https://doi.org/10.1016/j.jrp.2014.10.009

Garland, E. L., Fredrickson, B., Kring, A. M., Johnson, D. P., Meyer, P. S., \& Penn, D. L. (2010). Upward spirals of positive emotions counter downward spirals of negativity: Insights from the broaden-and-build theory and affective neuroscience on the 
treatment of emotion dysfunctions and deficits in psychopathology. Clinical Psychology Review, 849-864. https://doi.org/10.1016/j.cpr.2010.03.002

Gosling, S. D. (2008). Snoop: What your stuff says about you. New York, NY, US: Basic Books.

Graham, L. T., Sandy, C. J., \& Gosling, S. D. (2011). Manifestations of individual differences in physical and virtual environments. In T. (Ed) Chamorro-Premuzic, S. (Ed) von Stumm, \& A. (Ed) Furnham (Eds.), The Wiley-Blackwell handbook of individual differences. (pp. 773-800). Wiley-Blackwell.

Greischel, H., Noack, P., \& Neyer, F. J. (2016). Sailing uncharted waters: Adolescent personality development and social relationship experiences during a year abroad. Journal of Youth and Adolescence, 45, 2307-2320. https://doi.org/10.1007/s10964016-0479-1

Haller, C. S. (2017). The relatives' big five personality influences the trajectories of recovery of patients after severe TBI: A multilevel analysis. Journal of Personality, 85, 481493. https://doi.org/10.1111/jopy.12254

Hampson, S. E., \& Friedman, H. S. (2008). Personality and health: A lifespan perspective. In O. P. John, R. W. Robins, \& L. A. Pervin (Eds.), Handbook of personality (3rd ed., pp. 770-794). New York: Guilford Press.

Hartup, W. W., \& Stevens, N. (1997). Friendships and adaptation in the life course. Psychological Bulletin, 121, 355-370. https://doi.org/10.1037/0033-2909.121.3.355

Heller, D., Watson, D., \& Ilies, R. (2004). The role of person versus situation in life satisfaction: A critical examination. Psychological Bulletin, 130, 574-600. https://doi.org/10.1037/0033-2909.130.4.574

House, J. S., Landis, K. R., \& Umberson, D. (1988). Social relationships and health. Science, $241,540-545$.

Hutteman, R., Hennecke, M., Orth, U., Reitz, A. K., \& Specht, J. (2014). Developmental tasks as a framework to study personality development in adulthood and old age. 
European Journal of Personality, 28, 267-278. https://doi.org/10.1002/per.1959 Jeronimus, B. F. (2015). Environmental influences on neuroticism: A story about emotional (in) stability. Groningen: University of Groningen. Retrieved from http://dx.doi.org/10.13140/2.1.3452.2407

Jeronimus, B. F., Kotov, R., Riese, H., \& Ormel, J. (2016). Neuroticism’s prospective association with mental disorders: A meta-analysis on 59 longitudinal/prospective studies with 443,313 participants. Psychological Medicine, 46, 2883-2906. https://doi.org/10.1017/S0033291716001653

Jeronimus, B. F., Ormel, J., Aleman, A., Penninx, B. W., \& Riese, H. (2013). Negative and positive life events predict small but long-term change in neuroticism. Psychological Medicine, 43(11), 2403-2415. https://doi.org/10.1017/S0033291713000159

Jeronimus, B. F., Riese, H., Sanderman, R., \& Ormel, J. (2014). Mutual Reinforcement Between Neuroticism and Life Experiences: A Five-Wave, 16-Year Study to Test Reciprocal Causation. Journal of Personality and Social Psychology, 107, 751-64. https://doi.org/10.1037/a0037009

John, O. P., Naumann, L. P., \& Soto, C. J. (2008). Paradigm shift to the integrative Big Five trait taxonomy: History, measurement, and conceptual issues. In O. P. John, R. W. Robins, \& L. A. Pervin (Eds.), Handbook of personality: theory and research (3rd ed.). (3rd ed., pp. 114-158). New York: Guilford Press.

Jokela, M., Alvergne, A., Pollet, T. V., \& Lummaa, V. (2011). Reproductive behavior and personality traits of the five factor model. European Journal of Personality, 25, 487500. https://doi.org/10.1002/per.822

Jokela, M., Kivimäki, M., Elovainio, M., \& Keltikangas-Järvinen, L. (2009). Personality and having children: A two-way relationship. Journal of Personality and Social Psychology, 96, 218-230. https://doi.org/10.1037/a0014058

Jonkmann, K., Thoemmes, F., Lüdtke, O., \& Trautwein, U. (2014). Personality traits and living arrangements in young adulthood: Selection and socialization. Developmental 
Psychology, 50, 683-698. https://doi.org/10.1037/a0034239

Karney, B. R., \& Bradbury, T. N. (1995). The longitudinal course of marital quality and stability: A review of theory, methods, and research. Psychological Bulletin, 118, $3-$ 34. https://doi.org/10.1037/0033-2909.118.1.3

Karney, B. R., \& Bradbury, T. N. (1997). Neuroticism, marital interaction, and the trajectory of marital satisfaction. Journal of Personality and Social Psychology, 72, 1075 1092. https://doi.org/10.1037/0022-3514.72.5.1075

Kenny, D. A., Kashy, D. A., \& Cook, W. L. (2006). Dyadic data analysis. New York, NY, US: Guilford Press.

Kern, M. L., \& Friedman, H. S. (2011). Personality and pathways of influence on physical health. Social and Personality Psychology Compass, 5, 76-87. https://doi.org/10.1111/j.1751-9004.2010.00331.x

Kosinski, M., Stillwell, D., \& Graepel, T. (2013). Private traits and attributes are predictable from digital records of human behavior. Proceedings of the National Sciences of America, 110(15), 5802-5805. https://doi.org/10.1073/pnas.1218772110

Laceulle, O. M., Jeronimus, B. F., van Aken, M. A. G., \& Ormel, J. (2015). Why Not Everyone Gets Their Fair Share of Stress: Adolescent's Perceived Relationship Affection Mediates Associations Between Temperament and Subsequent Stressful Social Events. European Journal of Personality, 29(2), 125-137. https://doi.org/10.1002/per.1989

Landis, B. (2016). Personality and social networks in organizations: A review and future directions. Journal of Organizational Behavior, 37, S107-S121. https://doi.org/10.1002/job.2004

Lang, F. R., Reschke, F. S., \& Neyer, F. J. (2006). Social relationships, transitions, and personality development across the life span. In D. K. Mroczek \& T. D. Little (Eds.), Handbook of personality development (pp. 445-466). Mahwah: Lawrence Erlbaum. Laursen, B., \& Hafen, C. A. (2010). Future directions in the study of close relationships: 
Conflict is bad (except when It's not). Social Development, 19, 858-872. https://doi.org/10.1111/j.1467-9507.2009.00546.x

Lehnart, J., \& Neyer, F. J. (2006). Should I stay or should I go? Attachment and personality in stable and instable romantic relationships. European Journal of Personality, 20, 475-495. https://doi.org/10.1002/per.606

Lehnart, J., Neyer, F. J., \& Eccles, J. (2010). Long-term effects of social investment: The case of partnering in young adulthood. Journal of Personality, 78, 639-670. https://doi.org/10.1111/j.1467-6494.2010.00629.x

Lerner, R. M. (1996). Relative plasticity, integration, temporality, and diversity in human development: A developmental contextual perspective about theory, process, and method. Developmental Psychology, 32, 781-786. https://doi.org/10.1037/00121649.32.4.781

Lerner, R. M., \& Overton, W. F. (2008). Exemplifying the integrations of the relational developmental system: Synthesizing theory, research, and application to promote positive development and social justice. Journal of Adolescent Research, 23, 245255. https://doi.org/10.1177/0743558408314385

Löckenhoff, C. E., Terracciano, A., Patriciu, N. S., Eaton, W. W., \& Costa, P. T. (2009). Self-reported extremely adverse life events and longitudinal changes in five-factor model personality traits in an urban sample. J Trauma Stress, 22(1), 53-59. https://doi.org/10.1002/jts.20385

Lodi-Smith, J., \& Roberts, B. W. (2007). Social investment and personality: A meta-analysis of the relationship of personality traits to investment in work, family, religion, and volunteerism. Personality and Social Psychology Review, 11(1), 68-86. https://doi.org/10.1177/1088868306294590

Longua, J., Dehart, T., Tennen, H., \& Armeli, S. (2009). Personality Moderates the Interaction between Positive and Negative Daily Events Predicting Negative Affect and Stress. Journal of Research in Personality, 43(4), 547-555. 
https://doi.org/10.1016/j.jrp.2009.02.006

Lüdtke, O., Roberts, B. W., Trautwein, U., \& Nagy, G. (2011). A random walk down university avenue: Life paths, life events, and personality trait change at the transition to university life. Journal of Personality and Social Psychology, 101, 620-637. https://doi.org/10.1037/a0023743

Luhmann, M., \& Eid, M. (2009). Does it really feel the same? Changes in life satisfaction following repeated life events. Journal of Personality and Social Psychology, 97, 363-381. https://doi.org/10.1037/a0015809

Luhmann, M., Orth, U., Specht, J., Kandler, C., \& Lucas, R. E. (2014). Studying changes in life circumstances and personality: It's about time. European Journal of Personality, 28(3), 256-266. https://doi.org/10.1002/per.1951

Magnus, K., Diener, E., Fujita, F., \& Pavot, W. (1993). Extraversion and neuroticism as predictors of objective life events: A longitudinal analysis. Journal of Personality and Social Psychology, 65, 1046-1053. https://doi.org/10.1037/0022-3514.65.5.1046

Magnusson, D. (1990). Personality development from an interactional perspective. In L. Pervin (Ed.), Handbook of personality: Theory and research (pp. 193-222). New York: Guilford Press.

Magnusson, D., \& Törestad, B. (1993). A holistic view of personality: A model revisited. Annual Review of Psychology, 44, 427-452. https://doi.org/10.1146/annurev.ps.44.020193.002235

Malouff, J. M., Thorsteinsson, E. B., Schutte, N. S., Bhullar, N., \& Rooke, S. E. (2010). The Five-Factor Model of personality and relationship satisfaction of intimate partners: A meta-analysis. Journal of Research in Personality, 44, 124-127. https://doi.org/10.1016/j.jrp.2009.09.004

Marshall, E. M., Simpson, J. A., \& Rholes, W. S. (2015). Personality, communication, and depressive symptoms across the transition to parenthood: A dyadic longitudinal investigation. European Journal of Personality, 29, 216-234. 
https://doi.org/10.1002/per.1980

McAdams, D. P. (1995). What do we know when we know a person? Journal of Personality, 63, 365-396. https://doi.org/10.1111/j.1467-6494.1995.tb00500.x

McAdams, D. P., \& Pals, J. L. (2006). A new Big Five: Fundamental principles for an integrative science of personality. American Psychologist, 61, 204-217. https://doi.org/10.1037/0003-066X.61.3.204

McCabe, K. O., \& Fleeson, W. (2012). What is extraversion for? Integrating trait and motivational perspectives and identifying the purpose of extraversion. Psychological Science, 23, 1498-1505. https://doi.org/10.1177/0956797612444904

McCabe, K. O., \& Fleeson, W. (2016). Are traits useful? Explaining trait manifestations as tools in the pursuit of goals. Journal of Personality and Social Psychology, 110, 287301. https://doi.org/10.1037/a0039490

McCrae, R. R., \& Costa, P. T. (2008). The Five-Factor Theory of personality. In O. P. John, R. W. Robins, \& L. A. Pervin (Eds.), Handbook of personality: Theory and research (3rd ed.). (3rd ed., pp. 159-181). New York: Guilford Press.

McNulty, J. K. (2008). Neuroticism and interpersonal negativity: The independent contributions of perceptions and behaviors. Personality and Social Psychology Bulletin, 34, 1439-1450. https://doi.org/10.1177/0146167208322558

Mund, M., Finn, C., Hagemeyer, B., \& Neyer, F. J. (2016). Understanding dynamic transactions between personality traits and partner relationships. Current Directions in Psychological Science, 25, 411-416. https://doi.org/10.1177/0963721416659458

Mund, M., \& Neyer, F. J. (2014). Treating personality-relationship transactions with respect: Narrow facets, advanced models, and extended time frames. Journal of Personality and Social Psychology, 107, 352-368. https://doi.org/10.1037/a0036719

Mund, M., Zimmermann, J., \& Neyer, F. J. (in press). Personality development in adulthood. In V. Zeigler-Hill \& T. K. Shackelford (Eds.), The SAGE handbook of personality and individual differnces. Los Angeles: SAGE. 
Nestler, S., Grimm, K. J., \& Schönbrodt, F. D. (2015). The social consequences and mechanisms of personality: How to analyse longitudinal data from individual, dyadic, round-robin and network designs. European Journal of Personality, 29, 272-295. https://doi.org/10.1002/per.1997

Neyer, F. J., \& Asendorpf, J. B. (2001). Personality-relationship transaction in young adulthood. Journal of Personality and Social Psychology, 81, 1190-1204. https://doi.org/10.1037//0022-3514.81.6.1190

Neyer, F. J., \& Lehnart, J. (2006). Personality, relationships, and health: A dynamictransactional perspective. In M. E. Vollrath (Ed.), Handbook of personality and health (pp. 195-213). Chichester: Wiley.

Neyer, F. J., \& Lehnart, J. (2007). Relationships matter in personality development: Evidence from an 8-year longitudinal study across young adulthood. Journal of Personality, 75, 535-568. https://doi.org/10.1111/j.1467-6494.2007.00448.x

Neyer, F. J., Mund, M., Zimmerman, J., \& Wrzus, C. (2014). Personality-relationship transactions revisited. Journal of Personality, 82(5), 539-550. https://doi.org/10.1111/jopy.12063

Neyer, F. J., Wrzus, C., Wagner, J., \& Lang, F. R. (2011). Principles of relationship differentiation. European Psychologist, 16, 267-277. https://doi.org/10.1027/1016$9040 / \mathrm{a} 000055$

Noftle, E. E., \& Shaver, P. R. (2006). Attachment dimensions and the big five personality traits: Associations and comparative ability to predict relationship quality. Journal of Research in Personality, 40, 179-208. https://doi.org/10.1016/j.jrp.2004.11.003

Nolen-Hoeksema, S. (2000). The role of rumination in depressive disorders and mixed anxiety/depressive symptoms. Journal of Abnormal Psychology, 109, 504-511. https://doi.org/10.1037/0021-843X.109.3.504

Nolen-Hoeksema, S., Wisco, B. E., \& Lyubomirsky, S. (2008). Rethinking rumination. Perspectives on Psychological Science, 3, 400-424. https://doi.org/10.1111/j.1745- 
6924.2008.00088.x

Ormel, J., VonKorff, M., Jeronimus, B. F., \& Riese, H. (2017). Set-point Theory and Personality Development: Reconciliation of a Paradox. In J. Specht (Ed.), Personality Development Across the Lifespan (pp. 117-137). London: Elsevier.

Parker, P. D., Lüdtke, O., Trautwein, U., \& Roberts, B. W. (2012). Personality and relationship quality during the transition from high school to early adulthood. Journal of Personality, 80, 1061-1089. https://doi.org/10.1111/j.1467-6494.2012.00766.x

Poulton, R. G., \& Andrews, G. (1992). Personality as a cause of adverse life events. Acta Psychiatrica Scandinavica, 85(1), 35-38. https://doi.org/10.1111/j.16000447.1992.tb01439.x

Rammstedt, B., \& Schupp, J. (2008). Only the congruent survive: Personality similarities in couples. Personality and Individual Differences, 45, 533-535. https://doi.org/10.1016/j.paid.2008.06.007

Reis, H. T., Collins, W. A., \& Berscheid, E. (2000). The relationship context of human behavior and development. Psychological Bulletin, 126, 844-872. https://doi.org/10.1037//0033-2909.126.6.844

Reitz, A. K., Zimmermann, J., Hutteman, R., Specht, J., \& Neyer, F. J. (2014). How peers make a difference: The role of peer groups and peer relationships in personality development. European Journal of Personality, 28, 279-288. https://doi.org/10.1002/per.1965

Riese, H., Snieder, H., Jeronimus, B. F., Korhonen, T., Rose, R. J., Kaprio, J., \& Ormel, J. (2014). Timing of Stressful Life Events Affects Stability and Change of Neuroticism. European Journal of Personality, 28(2), 193-200. https://doi.org/10.1002/per.1929

Rindfuss, R. R. (1991). The young adult years: Diversity, structural change, and fertility. Demography, 28, 493-512. https://doi.org/10.2307/2061419

Roberts, B. W., Kuncel, N. R., Shiner, R., Caspi, A., \& Goldberg, L. R. (2007). The power of personality: The comparative validity of personality traits, socioeconomic status, and 
cognitive ability for predicting important life outcomes. Perspectives on Psychological Science, 2, 313-345. https://doi.org/10.1111/j.1745-6916.2007.00047.x

Roberts, B. W., \& Nickel, L. B. (2017). A critical evaluation of the Neo-Socioanalytic Model of personality. In J. Specht (Ed.), Personality Development Across the Lifespan (pp. 157-177). London: Elsevier.

Robins, R. W., Caspi, A., \& Moffitt, T. E. (2002). It's not just who you're with, it's who you are: Personality and relationship experiences across multiple relationships. Journal of Personality, 70, 925-964. https://doi.org/10.1111/1467-6494.05028

Robles, T. F., Slatcher, R. B., Trombello, J. M., \& McGinn, M. M. (2014). Marital quality and health: A meta-analytic review. Psychological Bulletin, 140, 140-187. https://doi.org/10.1037/a0031859

Ruiz, J. M., Matthews, K. A., Scheier, M. F., \& Schulz, R. (2006). Does who you marry matter for your health? Influence of patients' and spouses' personality on their partners' psychological well-being following coronary artery bypass surgery. Journal of Personality and Social Psychology, 91, 255-267. https://doi.org/10.1037/00223514.91 .2 .255

Sbarra, D. A. (2015). Divorce and health: Current trends and future directions. Psychosomatic Medicine, 77, 227-236. https://doi.org/10.1097/PSY.0000000000000168

Schmitt, D. P. (2004). The Big Five related to risky sexual behaviour across 10 world regions: Differential personality associations of sexual promiscuity and relationship infidelity. European Journal of Personality, 301-319. https://doi.org/10.1002/per.520

Selfhout, M., Burk, W., Branje, S., Denissen, J., van Aken, M., \& Meeus, W. (2010). Emerging late adolescent friendship networks and big five personality traits: A social network approach. Journal of Personality, 78, 509-538. https://doi.org/10.1111/j.1467-6494.2010.00625.x

Specht, J. (2017). Personality development in reaction to major life events. In J. Specht (Ed.), 
Personality Development Across the Lifespan (pp. 341-356). London: Elsevier.

Specht, J., Egloff, B., \& Schmukle, S. C. (2011). Stability and change of personality across the life course: The impact of age and major life events on mean-level and rank-order stability of the Big Five. Journal of Personality and Social Psychology, 101, 862-882. https://doi.org/10.1037/a0024950

Sturaro, C., Denissen, J. J. A., van Aken, M. A. G., \& Asendorpf, J. B. (2008). Personenvironment transactions during emerging adulthood: The interplay between personality characteristics and social relationships. European Psychologist, 13, 1-11. https://doi.org/10.1027/1016-9040.13.1.1

Sutin, A. R., Costa, P. T., Wethington, E., \& Eaton, W. (2010). Turning points and lessons learned: Stressful life events and personality trait development across middle adulthood. Psychology and Aging, 25, 524-533. https://doi.org/10.1037/a0018751

Thai, S., \& Page-Gould, E. (in press). ExperienceSampler: An open-source scaffold for building smartphone apps for experience sampling. Psychological Methods. https://doi.org/10.1037/met0000151

Vaidya, J. G., Gray, E. K., Haig, J., \& Watson, D. (2002). On the temporal stability of personality: Evidence for differential stability and the role of life experiences. Journal of Personality and Social Psychology, 83(6), 1469-84. https://doi.org/10.1037/00223514.83.6.1469

van der Krieke, L., Blaauw, F., Emerencia, A. C., Schenk, M., Slaets, J., Bos, E. H., ... Jeronimus, B. F. (2016). Temporal Dynamics of Health and Well-Being: A Crowdsourcing Approach to Momentary Assessments and Automated Generation of Personalized Feedback. Psychosomatic Medicine, 79, 213-223. https://doi.org/10.1097/PSY.0000000000000378 van der Krieke, L., Jeronimus, B. F., Blaauw, F., Wanders, R. B. K., Emerencia, A. C., Schenk, M., ... De Jonge, P. (2015). HowNutsAreTheDutch (HoeGekIsNL): A crowdsourcing study of mental symptoms and strengths. International Journal of 
Methods in Psychiatric Research, 25, 123-144. https://doi.org/10.1002/mpr.1495 van Os, J., Park, S. B. G., \& Jones, P. B. (2001). Neuroticism, life events and mental health: Evidence for person-environment correlation. The British Journal of Psychiatry, 178, 72-77. https://doi.org/10.1192/bjp.178.40.s72

van Scheppingen, M. A., Jackson, J. J., Specht, J., Hutteman, R., Denissen, J. J. A., \& Bleidorn, W. (2016). Personality trait development during the transition to parenthood: A test of the social investment theory. Social Psychology and Personality Science, 7(5), 452-462. https://doi.org/10.1177/1948550616630032

Wagner, J., Becker, M., Lüdtke, O., \& Trautwein, U. (2015). The first partnership experience and personality development: A propensity score matching study in young adulthood. Social Psychological and Personality Science, 6, 455-463. https://doi.org/10.1177/1948550614566092

Wagner, J., Lüdtke, O., Jonkmann, K., \& Trautwein, U. (2013). Cherish yourself: Longitudinal patterns and conditions of self-esteem change in the transition to young adulthood. Journal of Personality and Social Psychology, 104, 148-163. https://doi.org/10.1037/a0029680

Wagner, J., Lüdtke, O., Roberts, B. W., \& Trautwein, U. (2014). Who belongs to me? Social relationship and personality characteristics in the transition to young adulthood. European Journal of Personality, 28, 586-603. https://doi.org/10.1002/per.1974

Watson, D., Klohnen, E. C., Casillas, A., Nus Simms, E., Haig, J., \& Berry, D. S. (2004). Match makers and deal breakers: Analyses of assortative mating in newlywed couples. Journal of Personality, 72, 1029-1068. https://doi.org/10.1111/j.00223506.2004.00289.x

Weidmann, R., Schönbrodt, F. D., Ledermann, T., \& Grob, A. (2017). Concurrent and longitudinal dyadic polynomial regression analyses of Big Five traits and relationship satisfaction: Does similarity matter? Journal of Research in Personality, 70, 6-15. https://doi.org/10.1016/j.jrp.2017.04.003 
Winter, D. G., John, O. P., Stewart, A. J., Klohnen, E. C., \& Duncan, L. E. (1998). Traits and motives: Toward an integration of two traditions in personality research. Psychological Review, 105, 230-250. https://doi.org/10.1037/0033-295X.105.2.230

Wood, D., Gardner, M. H., \& Harms, P. D. (2015). How functionalist and process approaches to behavior can explain trait covariation. Psychological Review, 122, 84-111. https://doi.org/10.1037/a0038423

Wood, D., \& Roberts, B. W. (2006a). Cross-sectional and longitudinal tests of the personality and role identity structural model (PRISM). Journal of Personality, 74, 779-809. https://doi.org/10.1111/j.1467-6494.2006.00392.xWood

Wood, D., \& Roberts, B. W. (2006b). The effect of age and role information on expectations for Big Five personality traits. Personality and Social Psychology Bulletin, 32(11), 1482-1496. https://doi.org/10.1177/0146167206291008

Wrzus, C., Hänel, M., Wagner, J., \& Neyer, F. J. (2013). Social network changes and life events across the life span: A meta-analysis. Psychological Bulletin, 139, 53-80. https://doi.org/10.1037/a0028601

Wrzus, C., \& Mehl, M. R. (2015). Lab and/or field? Measuring personality processes and their social consequences. European Journal of Personality, 29, 250-271. https://doi.org/10.1002/per.1986

Wrzus, C., \& Neyer, F. J. (2016). Co-development of personality and friendships across the lifespan: An empirical review on selection and socialization. European Psychologist, 21, 254-273. https://doi.org/10.1027/1016-9040/a000277

Wrzus, C., Wagner, J., \& Neyer, F. J. (2012). The interdependence of horizontal family relationships and friendships relates to higher well-being. Personal Relationships, 19, 465-482. https://doi.org/10.1111/j.1475-6811.2011.01373.x

Wrzus, C., Zimmermann, J., Mund, M., \& Neyer, F. J. (2016). Friendships in young and middle adulthood: Normative patterns and personality differences. In M. Hojjat \& A. Moyer (Eds.), The psychology of friendship (pp. 21-38). Oxford: Oxford University 
Press.

Zhou, Y., Wang, K., Chen, S., Zhang, J., \& Zhou, M. (2017). An exploratory investigation of the role of openness in relationship quality among emerging adult Chinese couples. Frontiers in Psychology, 8. https://doi.org/10.3389/fpsyg.2017.00382

Zimmermann, J., \& Neyer, F. J. (2013). Do we become a different person when hitting the road? Personality development of Sojourners. Journal of Personality and Social Psychology, 105, 515-530. https://doi.org/10.1037/a0033019 


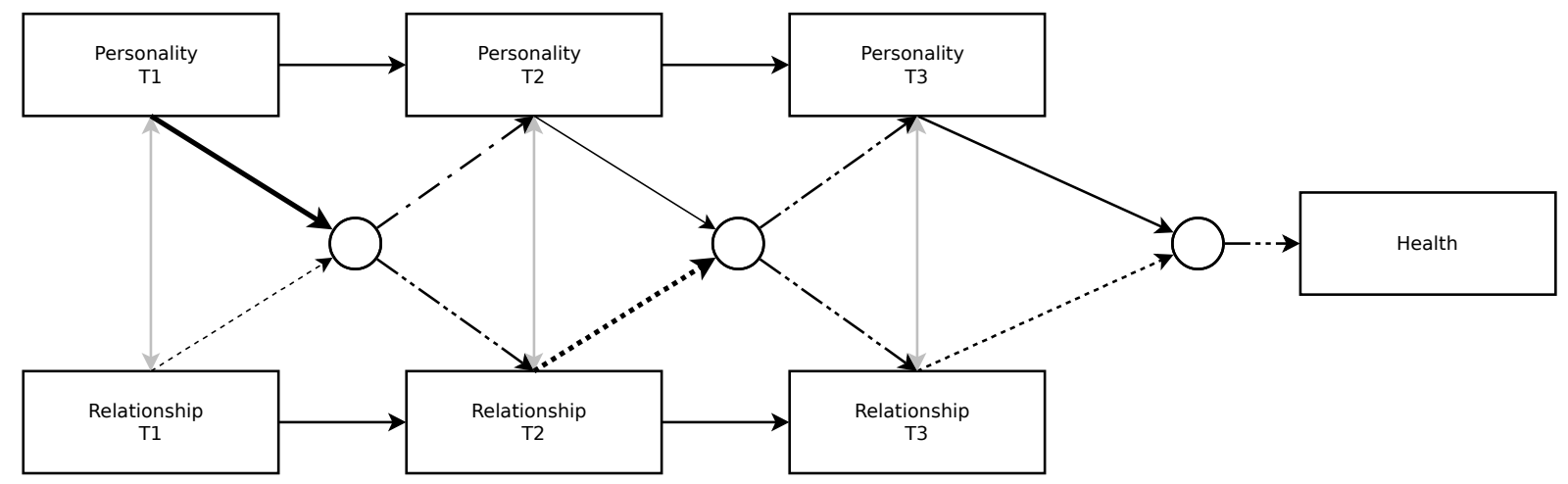

Figure 1. Generic display of personality-transactions and their effects on health outcomes.

Solid lines represent personality/selection effects, dotted lines represent relationship effects.

Dashed-and-dotted lines indicate effects that result from transactions between personality traits and relationships. Circles indicate micro-processes in personality-relationship transactions. The thickness of the paths indicate their relative strength. 


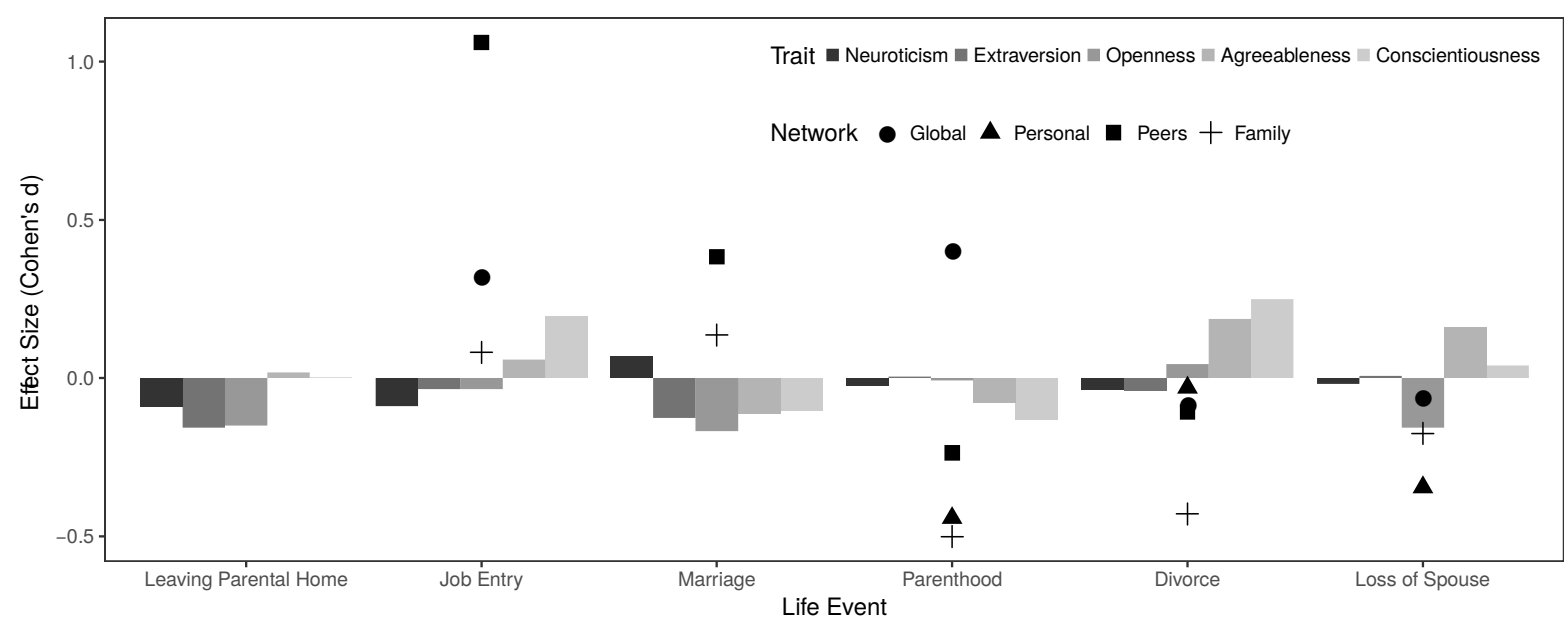

Figure 2. Most major life transitions affect both personality traits and the size of social networks. Data for changes in personality traits is taken from Specht et al. (2011), data for changes in social networks is derived from Wrzus et al. (2013). The global network comprises all social ties of an individual including family members, friends, colleagues, neighbors, fellow club members etc. The personal network comprises relationships with emotionally closer ties such as family members, friends, and other confidants. The peer network comprises interaction partners with roughly the same age such as friends and colleagues. The family network, finally, comprises all kin relationships (parents, children, siblings, etc.; Wrzus et al., 2013). 


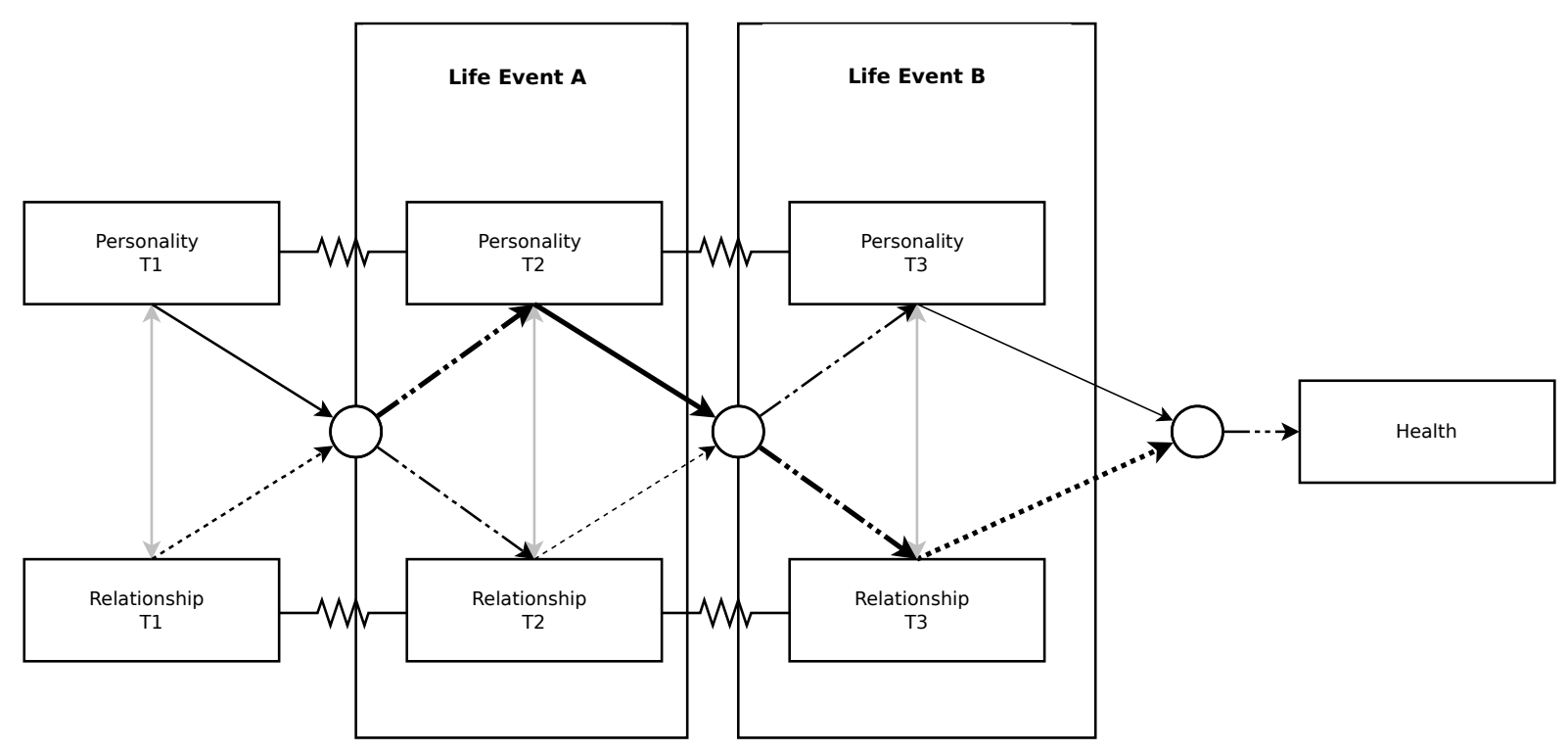

Figure 3. Patterns of personality-relationship transactions as displayed in Figure 1 can be altered by life events. Life events can affect the stability of both personality traits and social relationships (zig-zag lines) even before the event has actually occurred. Solid lines represent personality/selection effects, dotted lines represent relationship effects. Dashed-and-dotted lines indicate effects that result from transactions between personality traits and relationships. Circles indicate micro-processes in personality-relationship transactions. The thickness of the paths indicate their relative strength. The patterns of personality-relationship transactions altered by life events can have stronger effects on either the relationship or personality traits, which is indicated by the thickness of the dashed-and-dotted lines. 


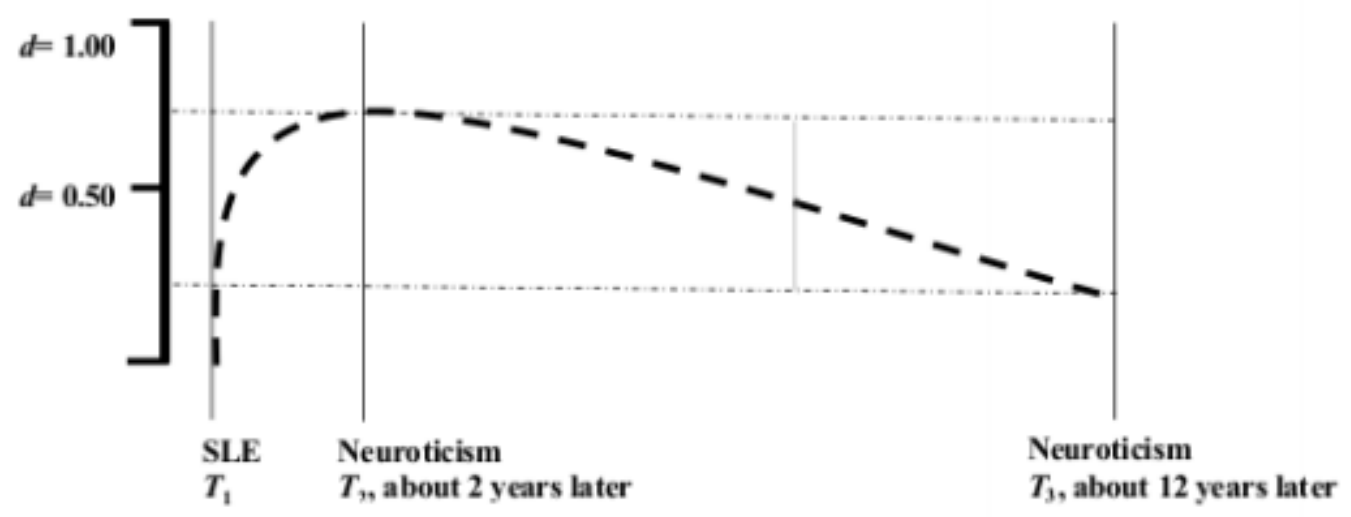

Figure 4. Graphical representation of long-term adaptation processes for the setpoint of neuroticism after stressful life events (SLE) such as the death of a spouse. Shortly after the event, neuroticism is elevated by a Cohen's $d$ of about 0.70 , but decreases over the subsequent decade (derived from Jeronimus, 2015, p. 243). 